\title{
ANALYSIS
}

\section{9 \\ Elections and nation-building: the long road since 1970}

\section{Robbie Robertson}

In Fiji it is communalism that has most given distinctive shape to politics and vice versa. When Fiji became independent in 1970, its freshly negotiated constitution endorsed a communal basis for voting. This was not surprising given that colonialism had divided the country ethnically, with each community isolated from the other geographically, economically, educationally and socially. ${ }^{1}$ Industrial and political forms of organization - often closely related - also assumed ethnic characteristics. Indo-Fijian cane-farmer organizations easily transformed into political parties, the most notable being the Federation Party (formed in 1963) and the shorter-lived Indian Alliance (formed in 1966). Fijian organizations similarly derived in part from the chiefly-led and vanua-structured Fijian Association, which, after 1956, lobbied for Fijian interests.

However, social change would always sorely test such neat ethnic demarcations. Indeed, these early political developments can easily be read as attempts to deal with social change: for Fijians the gradual breakdown of communal lifestyles; for Indo-Fijians the need to correct the perceived injustices of colonial practice. But long before colonialism ended, the limitations of communalism had become obvious for those who wished to see them. As urbanization gathered pace and employment patterns changed, new multiracial unions began to form and make their presence felt, the most notable example being the 1959 Fiji oil workers' strike in Suva. 
Although the impact of colonial pressures diminished in the 1950s and 1960s, the illogic of communalism continued to affect the operation of political parties. As an independent country, Fiji's prosperity would be tied closely to cooperation between its communities. After all, Fijians would rely on income derived from sugar - then the country's greatest annual source of wealth - to fund the programs that they envisaged would lift Fijian economic performance. Antagonizing Indo-Fijians - the main producers of sugar - could hardly help their cause. Both communities might appear to have had separate goals, but neither could achieve them without the other's support. The zero-sum attitudes fostered during colonialism had the potential to seriously erode nation-building efforts; certainly they hindered the evolution of at least one aspect of nationbuilding - national identity.

Interdependence was the new reality and, as the country neared independence, it was reflected in political manoeuvrings: in 1968 the largely Indo-Fijian Federation Party joined forces with the small Fijian National Democrats party, based in the west of Viti Levu, to become the National Federation Party (NFP); and the Fijian Association became the dominant component of the Alliance Party (established in 1966), which itself was made up of the Indian Alliance and the General Electors Association (GEA). (The GEA represented citizens who were neither Fijian nor Indo-Fijian.) The Alliance was more successful than the NFP, capturing 84 per cent of the Fijian vote in 1972, as well as, between 1972 and 1987, 16-24 per cent of the Indo-Fijian vote and nearly 90 per cent of the General vote. In fact, it owed much of its success to this wide appeal, especially among the General voters population, which effectively held the balance of power.

Even the 1970 constitution represented accommodation between the communities. Indo-Fijians had wanted a simple one person/one vote system in single electorates, but accepted the Fijian wish for a communal-based constitution on the understanding that a degree of cross-voting would prepare Fiji for a less communal-based electoral system in the future. That future is yet to arrive, not so much because communalism itself is entrenched, but because the political parties, themselves communal, appear resistant to change. This outcome was not necessarily apparent to the framers of the 1970 constitution, who declared that the Lower House would be made up of 22 representatives 
of the Fijian community, 22 representatives of the Indo-Fijian community and 8 members representing the remaining voters. Twenty-seven of the 52 seats were communal seats; that is, members of each community voted for their own communal representative, thereby producing 12 Fijian, 12 Indo-Fijian and three General members. In the remaining 25 General Communal constituencies, everyone had three additional votes to elect a suitable Fijian, Indo-Fijian and General elector representative; resulting in 10 Fijian, 10 Indo-Fijian and five General elector representatives, respectively.

This constitutional form of post-colonial accommodation - promoted politically as multiracialism - had two principal weaknesses. First, despite the appearance of multiracial political groupings, the two main parties each remained dominated by a different community. No amount of cross-voting could disguise the constitution's emphasis on communal identification as the basis for political activity. This effectively made intra-communal divisions more politically damaging than inter-communal rivalry because the former threatened the party itself. Second, it held communities hostage to the fortunes of their political parties. To succeed, parties had to demand communal unity. Issues of leadership or governance always took second place. Not surprisingly, the zerosum logic of political competition soon superseded the cooperative ideal fostered by the post-colonial ideology of multiracialism. Party survival demanded it. Communal unity always came first. Thus, the ideology of multiracialism and the cooperative nation-building it underpinned were undermined by the very structures it promoted.

The weaknesses discussed above are the ones that have most shaped Fiji's politics since independence in 1970, with the coups of 1987 and 2000 being extreme manifestations of the same features, in that they represented extralegal means for the Fijian governing élite to overcome the effects of communal disunity. However, such reactions failed to acknowledge that the cause of communal disunity did not lie in inter-communal rivalry. The political system only gave that appearance.

Community disunity has largely resulted from two factors. The first has to do with popular expectations that independence would deliver development. In part, as in any country, development would be affected by the quality and organizing skills of the country's leaders. It would also be affected by the 
strategies for development they pursued, and by the nature of the regional and global environment they confronted. All influenced the access to and availability of resources for meaningful development.

During the 1970s and 1980s, the external environment did provide new opportunities, which Fiji's leaders tapped into. The opportunities were in new timber, clothing and light manufacturing activities, and in the expansion of tourism and sugar production. Clothing and sugar, however, were dependent on preferential access to markets and, in the long term, these industries would suffer both from the global trend towards free trade and from the failure of political leaders to use preferences as the basis for economic diversification. But development would also be frustrated by the growing disjuncture between, first, rural and urban development and, second, state nationalist rhetoric and transnational economic linkages. In the 1970 s, the former was the greatest test of communal unity for the Alliance; in the 1980s, the latter. In many respects, it was development that most affected the 1990s. However, the push towards external alliances strengthened, and the local impact of these alliances was offset in part by the suspension of democracy (between 1987 and 1992) and in part by the introduction of the 1990 constitution, which consolidated Fijian political dominance. These offsetting factors did not of themselves address the key development issues facing the country, but they did highlight and make more obvious the key importance of leadership and governance as ingredients of development, thus providing new scope for division within all communal blocs.

The first three decades of independence demonstrated the fundamental weaknesses of communalism as the basis for political organization. Unity in both main communities depended on maintaining the status quo, yet the goal of communal leadership was development, which - whether successful or not - held the potential to destabilize the status quo as a result of the social change it effected. Over time, education alone created tensions; it either further raised expectations or helped expose the failures of leadership. Urbanization had a similar impact, but, in addition, it undermined communal distinctiveness, as more and more people from different communities lived together, worked together and schooled together. These were not rapid processes of change, although urbanization was more rapid in and after the 1990s because of the 
failure of rural development plans, the negative impact of the coups and poor leadership on economic growth. But the political impact of urbanization tended to be delayed because, initially, it brought together people with little experience of multiracial living, who sought to maintain their communal distinctiveness by way of urban settlements and social/religious associations. At least in the short term, urbanization created as many obstacles to multiracial accommodation as it resolved.

Accordingly, social change - although consistent throughout the first three decades of independence - was neither rapid nor necessarily politically destabilizing. Nonetheless, communal disunity could dramatically change party fortunes, as the Alliance Party first discovered in April 1977 when the dissident Fijian Nationalist Party, riding on the back of rural dissatisfaction with the pace of development, managed to secure 24 per cent of the Fijian vote and destroy the Alliance's majority. Only intra-communal (Muslim-Hindu) rivalries prevented the NFP from claiming a narrow victory and, in the subsequent September poll, the Alliance learned the value of raising the spectre of Indo-Fijian political dominance to offset indigenous Fijian divisions. This hardening of racial polarization increasingly came with notions of Fijian paramountcy - the idea that, as the original indigenous people of Fiji, Fijians possessed an inherent right to political rule. Indeed, by the same logic, they alone were permitted to use the national name to describe themselves. 'Indians' - for some, even use of the descriptor Indo-Fijian became contentious - were portrayed variously as foreigners or as guests ungrateful for the hospitality already given them by Fijians. Although, by the 1980s, transnational corporations, many of them in association with Fijian investment companies, clearly dominated the Fiji economy, Indo-Fijians monopolized very visible sectors, such as cane farming, transport and retail. This enabled Fijian nationalists to characterize their struggle as one against both Indo-Fijian political and Indo-Fijian economic domination. While Fijian nationalists saw their purpose as healing intra-communal division, such political campaigning carried immense dangers for stability and national development.

In many respects, the NFP never recovered from the ruptures of 1977 although it did manage to give the appearance of recovery in the 1982 election, when it regained much of the ground it had previously lost. It was assisted by a 
new coalition with a small western Fijian party (the Western United Front, or WUF) that won two seats on the strength of western Viti Levu dissatisfaction with the Alliance's handling of its pine resources. However, economic recession and conflict with trade unions shifted the focus of politics in the 1980s and left the still divided, business-oriented NFP increasingly marginalized. The vacuum was filled in 1985 by a Fiji Trade Union Congress-sponsored Fiji Labour Party (FLP), a multiracial alternative to both the Alliance and NFP, which declared that the handling of issues rather than race should be the crucial determinant of fitness for office. As a worker-based party, it wished to focus on economic and social issues that all communities faced in common, and which it felt the two main parties neglected because of their concentration on communalism. However, in late 1986, in a major change in tactics, the FLP formed a coalition with the NFP. In the following April 1987 election, as a result of increased Fijian support in four Suva open constituencies, where Labour's issues-based strategy had most appeal, this coalition narrowly defeated the Alliance government.

Labour's sudden victory demonstrated the impact social change could have on political outcomes, especially in open seats where margins were potentially tighter. For those who lost, it also demonstrated the inability of communalism as established under the 1970 constitution to maintain Fijian paramountcy. Consequently, in May 1987, the losers re-seized power through a military coup and introduced a completely new dimension to Fiji politics that survives to this day. For, once invited in, the military demonstrated great reluctance to return to the barracks. Although the Governor General, Ratu Sir Penaia Ganilau, succeeded in taking charge of the regime which came to power after the coup, he was powerless to control the military. Indeed, when he and former Alliance prime minister Ratu Sir Kamisese Mara sought to head off economic collapse by seeking accommodation with the ousted FLP, they were deposed in a second coup in September 1987. This time, the army imposed a military government on the country and, in order to forestall legal challenges, declared Fiji a republic. Military commander Sitiveni Rabuka did permit both chiefs to return to their respective positions as president and prime minister at the end of 1987, but, for the next five years, relations between the interim government and the military were strained. Indeed, once a new constitution was promulgated in 1990, Rabuka, to prevent any possibility of future Indo- 
Fijian political rule, moved swiftly to seize control of, first, the new political process - gaining leadership of a new Fijian establishment party (the Soqosoqo ni Vakavulewa ni Taukei or SVT) - and then, in 1992, the prime ministership. The SVT signaled the demise of multiracialism. Despite its shortcomings, the Alliance had at least symbolized a coalition of communities. The SVT made no such pretence; it was defiantly a Fijian-only party constructed on the basis of Fijian paramountcy.

The military's role as guardian of national security was enshrined in the new constitution. In addition, the new constitution specifically bestowed immunity from prosecution on all people who had engaged in the coups of 1987. It also strengthened communalism as a bulwark against social change, reserving all senior political and constitutional posts for Fijians, increasing the role of the Great Council of Chiefs, doing away with open seats and the cross-voting they entailed, provincializing Fijian electorates, and penalizing all communities deemed disloyal in 1987, including those of western and urban Fijians. It produced a 70-member lower house made up of 37 Fijians, 27 Indo-Fijians, five General Electors, and one Rotuman. Indo-Fijians no longer enjoyed equality with Fijians, and General Electors lost their once influential balance of power role. Urban Fijians, proportionately entitled to 13 seats, received only five, while provincial seats were disproportionately weighted to favour the eastern provinces of the chiefly establishment.

Ironically, this remaking of communalism failed to achieve one of its main objectives - Fijian reunification. Shorn of its raison d'être - the potential threat of Indo-Fijian dominance - the new Fijian governing party was never able to emulate the Alliance's command of Fijian support. In 1992, it gained 66 per cent of the Fijian vote, well short of the Alliance's 84 per cent in 1972. What the constitution did do, however, was to create a form of political apartheid in which each election resembled two separate elections, one Fijian and one Indo-Fijian, with the former representing a struggle between the governing party and dissident individuals and provinces, and the latter a struggle between two supposedly ideologically opposed (but, in reality, simply differently led in terms of style) parties for the hearts and minds of Indo-Fijians. While the former took government as its prize, the latter had to settle for opposition leadership. 
This system ended abruptly with the introduction in 1997 of another new constitution. The SVT's monopolization of power had not prevented political drift and economic decline; if anything, it had contributed to the malaise. Sham democracies that prevent the turnover of government, such as that created by the 1990 constitution, rarely provide a check on the exercise of political power. Perhaps sensing this, Rabuka sought to reinvent himself by forming a partnership across the communal divide with the NFP in order to reduce the most obvious obstacle to national development. But such a partnership represented a (largely unstated) recognition that 1987 had been a mistake and that the country needed to revert to the principles of multiracialism espoused in 1970. However, little was done to prepare Fijians for this transformation in political rhetoric. Rabuka refused to concede explicitly that 1987 had been a mistake, and planned vanua consultations on the new changes were never completed.

Nonetheless, the new constitution was promulgated. It introduced a new Lower House of 71 members derived from 46 communal and 25 open seats. Twenty-three of the communal seats were reserved for Fijians, 19 for IndoFijians, one for Rotumans and three for General electors. The constitution also foreshadowed Rabuka's planned partnership, by mandating that any party that received more than 10 per cent of the seats (that is, eight seats or more) had the right to share proportionately in cabinet posts. It also introduced a new system of voting - the alternative vote system - that was promoted as more likely to produce multiracial accommodation than the older first-past-the-post system. In practice, however, it didn't; it was to prove every bit as non-accommodating of minority views as its predecessor (see Fraenkel, this volume). Finally, although progressive compared with its predecessors (especially with respect to human rights), the new constitution's electoral provisions still produced large disparities in electorate sizes (particularly among Fijian communal constituencies) and still under-represented urban Fijians.

Nevertheless, the first election under the 1997 constitution, in May 1999, did produce a significantly different result, although more for political than electoral reasons. Uncertainty over the power-sharing provisions of the constitution and widespread dissatisfaction with SVT rule saw the latter's share 
of Fijian votes plummet to 38 per cent. The SVT's proposed partner, the NFP, suffered a worse fate, winning no seats at all. From this election, a new People's Coalition government emerged, dominated by a now strongly Indo-Fijian FLP, but partnered with very substantial dissident Fijian parties that, together, had garnered about 60 per cent of the Fijian vote. ${ }^{2}$ For this reason, perhaps, the FLP did not feel obliged to honour the constitution's power-sharing commitment; when the SVT imposed conditions on its involvement in a multiparty cabinet, the FLP rejected them and excluded the SVT from cabinet.

As in 1987, the upset victory was short-lived. On 19 May 2000, Fijian nationalists and a rebel military unit (originally established by Rabuka to protect his 1987 'revolution') staged a coup that, although ultimately unsuccessful for the coup-leaders, enabled the Fijian establishment to reassert itself and conduct - in 2001 - fresh elections, with a new all-Fijian party (the Soqosoqo Duavata ni Lewenivanua or SDL) that carried none of the baggage of its predecessor. Like the Alliance in the September 1977 election, the SDL employed nationalist rhetoric to heal Fijian divisions and to minimize the impact of another new Fijian party, the Conservative Alliance-Matanitu Vanua (CAMV), which was allied to the 2000 coup plotters. The tactic succeeded, and the new establishment party, the SDL, won 70 per cent of the Fijian vote (if the 20 per cent share of its eventual partner - the CAMV - is included). The FLP similarly consolidated its hold on Indo-Fijian support at the expense of the NFP, with the FLP winning 75 per cent of the Indo-Fijian vote. ${ }^{3}$ The result reflected the uncertainties created by the 1999 election and, more particularly, the 2000 coup, and the failure of the alternative vote system to give space to minority voices.

Such polarization also effectively meant that these uncertainties could not be easily resolved. Only inter-communal cooperation could have that impact, and, in the wake of 2000, with each party boxed in with their respective community, there was little possibility of cooperation. Thus, differences over land rentals, which had simmered all through the late 1990s, remained unresolved because of political obstinacy. The SDL went to the polls in 2001 on a platform of affirmative action for Fijians. The FLP opposed this as a form of racial discrimination, and, although differences between the parties were not great, rhetoric alone made a meeting of minds impossible. The SDL refused to 
entertain power-sharing with the FLP as the constitution mandated, just as the FLP had refused power-sharing with the SVT in 1999. However, unlike the SVT, the FLP rigorously pursued the matter through the courts until 2005, when it finally accepted a role as opposition party. Despite the basic legality of its position, its court action served to reduce possibilities for cooperation further.

In 2005, the SDL introduced a controversial Promotion of Reconciliation, Tolerance and Unity Bill, which Labour dismissed as an attempt to heal divisions within the Fijian community over post-coup investigations and prosecutions. The matter might have remained as yet another symbol of intercommunal division but for the military's defiant stand against the Bill. As a largely Fijian institution, the Republic of Fiji Military Forces had traditionally supported ruling Fijian parties. However, the 2000 coup revealed serious divisions within the military that were dramatically exacerbated in November of that year when the military unit responsible for the 2000 debacle suddenly mutinied. This second failed initiative hardened the military leadership against reconciliation and, during early 2006, its troops were displayed around the capital as a sign of its displeasure with the government, a move that was eerily reminiscent of its behaviour towards the interim government between 1988 and 1992. Prior to the 2006 election, its leadership even hinted at the possibility of a coup if its views were ignored. [See Ratuva, this volume.]

The unconstitutional role of the military was not the only issue of debate after 2000. Increasingly, the rapid decline in the Indo-Fijian population gained greater public recognition. ${ }^{4}$ Indeed, nearly one-quarter of the Indo-Fijian population had left Fiji in the two decades after 1987, and that decline had electoral implications, particularly in open seats. In effect, it meant that, in time, Indo-Fijians as a bloc were unlikely ever again to achieve political power in their own right, as they had in 1999. Instead, they would have to return to their roots, and devote more attention to developing a multiracial constituency. This was always one of the goals of power-sharing, and perhaps one reason why, at the conclusion of the 2006 election, both parties saw advantages in the practice that they had previously neglected. Certainly, it provided an opportunity to reduce political heat and effect a more cooperative environment in which to address the many unresolved issues that affected all communities alike. 
Whether such power-sharing accommodation will extend to the joint development of Bills to resolve these issues remains to be seen, but at the very least it suggests that, with political will and responsible leadership, a way can be found to overcome the inherent dangers communalism has always inflicted on the nation, and to create the necessary political trust on which to build a more responsive political system for the future. This has been the one undeniable lesson of Fiji's long road since 1970, a lesson Fiji has constantly been forced to confront after each occasion of communal polarization. Then, as now, the behaviour of political parties and their leaders have most determined the success or otherwise of multiracialism, and with it the development prospects of the country.

\section{Notes}

1 From the end of World War II until quite recently, Fijians and Indo-Fijians constituted approximately the same demographic proportion of the community.

2 The Party of National Unity (PANU) was a Ba-based party with four seats. The Fijian Association Party (FAP), founded in opposition to Rabuka in 1994, won 10 seats. These two parties were in coalition with Labour on the eve of the election. Not so, the Veitokani ni Lewenivanua Vakarisito (VLV), which had been set up as an unofficial Methodist party in opposition to the new constitution, and which demanded both the return of the 1987 'Sunday Ban' and that Fiji be declared a Christian state. Its three members promptly joined the People's Coalition after the election.

3 This communal polarization behind two large parties would be repeated in 2006, with both parties gaining around 81 per cent of their respective communal votes.

4 The Indo-Fijian population has fallen rapidly since 1987 and by 2006 is assumed to make up only 37 per cent of Fiji's total population. 